\title{
The Association between Parathyroid Hormone Levels and Hemoglobin in Diabetic and Nondiabetic Participants in the National Kidney Foundation's Kidney Early Evaluation Program
}

\author{
Imran Memon $^{a} \quad$ Keith C. Norris ${ }^{b} \quad$ Andrew S. Bomback ${ }^{c}$ Carmen Peralta $^{d}$ \\ Suying Li ${ }^{\mathrm{e}}$ Shu-Cheng Chen ${ }^{\mathrm{e}}$ Peter A. McCullough ${ }^{f-i}$ \\ Adam Whaley-Connell ${ }^{j, k} \quad$ Claudine Jurkovitz ${ }^{\prime}$ Manjula Kurella Tamuram \\ Georges Saab $^{n}$ for the Kidney Early Evaluation Program Investigators \\ a Department of Internal Medicine and Pediatrics, University of Michigan School of Medicine, \\ Ann Arbor, Mich., b Charles R. Drew University of Medicine and Science, Los Angeles, Calif., \\ 'Department of Medicine, Columbia University College of Physicians and Surgeons, New York, \\ N.Y., d Department of Medicine, University of California-San Francisco, San Francisco, Calif., \\ e Chronic Disease Research Group, Minneapolis Medical Research Foundation, Minneapolis, \\ Minn., ${ }^{f}$ St. John Providence Health System, Warren, Mich., ${ }^{9}$ St. John Hospital and Medical \\ Center, Detroit, Mich., h Providence Hospitals and Medical Centers, Southfield, Mich., and \\ iProvidence Park Heart Institute, Novi, Mich., jHarry S. Truman VA Medical Center and \\ kDivision of Nephrology and Hypertension, Department of Internal Medicine, University of \\ Missouri-Columbia School of Medicine, Columbia, Mo., 'Christiana Care, Center for Outcomes \\ Research, Newark, Del., m Geriatric Research Education Clinical Centers, US Department of \\ Veterans Affairs Palo Alto, Palo Alto, Calif., and ${ }^{\mathrm{n}}$ Department of Medicine, Metrohealth \\ Medical Center, Cleveland, Ohio, USA
}

\section{Key Words}

Chronic kidney disease · Anemia · Secondary hyperparathyroidism

\begin{abstract}
Background: Both anemia and secondary hyperparathyroidism are reflections of hormonal failure in chronic kidney disease (CKD). While the association of elevated levels of parathyroid hormone (PTH) and anemia has been studied among those with advanced CKD, less is known about this association in mild-to-moderate CKD. Methods: In a cross-sectional analysis, the relationship between PTH and hemoglobin levels was investigated in 10,750 participants in the National Kidney Foundation's Kidney Early Evaluation Program with an estimated glomerular filtration rate (eGFR) $<60 \mathrm{ml} / \mathrm{min} / 1.73 \mathrm{~m}^{2}$. Results: In the unadjusted analysis, higher PTH levels were associated with lower hemoglobin levels. However, after multivariable adjustment for age, race, gender, smoking status, education, cardiovascular disease, diabetes, hyperten-
\end{abstract}


Memon et al.: The Association between Parathyroid Hormone Levels and Hemoglobin in Diabetic and Nondiabetic Participants in the National Kidney Foundation's KEEP

sion, cancer, albuminuria, BMI, baseline eGFR, calcium, and phosphorus, the direction of association changed. As compared to the first PTH quintile, hemoglobin levels were $0.09 \mathrm{~g} / \mathrm{dl}$ (95\% CI: $0.01-0.18), 0.15 \mathrm{~g} / \mathrm{dl}$ (95\% CI: 0.07-0.24), $0.18 \mathrm{~g} / \mathrm{dl}$ (95\% CI: 0.09-0.26), and $0.13 \mathrm{~g} / \mathrm{dl}$ (95\% CI: 0.07-0.25) higher for the second, third, fourth, and fifth quintiles, respectively. Similarly, each standard deviation increase in natural log transformed PTH was associated with a $0.06 \mathrm{~g} / \mathrm{dl}$ (95\% CI: 0.03-0.09, $\mathrm{p}=0.0003$ ) increase in hemoglobin. However, a significant effect modification was seen for diabetes $(p=0.0003)$. Each standard deviation increase in natural log transformed PTH was associated with a $0.10 \mathrm{~g} / \mathrm{dl}(95 \%$ CI: $0.054-0.138, \mathrm{p}<0.0001)$ increase in hemoglobin, while no association was seen among those without diabetes mellitus. Conclusion: After multivariable adjustment, there was a small positive association between PTH and hemoglobin among diabetics but not among nondiabetics.

Copyright $@ 2013$ S. Karger AG, Basel

\section{Introduction}

The prevalence of anemia in chronic kidney disease (CKD) increases as renal function declines [1, 2]. Furthermore, the anemia occurs even among those with mild CKD [2] and may not be due to erythropoietin deficiency at these stages [3]. Despite this, one of the mainstays of treatment for the anemia of predialysis CKD has been the use of exogenous erythropoietin-stimulating agents. However, treatment with these agents has been associated with an increased risk of adverse events, including hypertension, stroke, and heart failure, when administered at higher doses [4, 5]. Given that higher hemoglobin concentrations may be associated with improved health-related quality of life scores in predialysis CKD [6], identifying other modifiable and non-modifiable factors in the pathogenesis of anemia is important.

One potential factor may be parathyroid hormone (PTH). In advanced CKD, high PTH levels may cause 'resistance' to erythropoietin by increasing bone marrow fibrosis [7]. Elevated PTH levels may also increase the osmotic fragility of red blood cells, leading to a shortened lifespan [8], or inhibit the proliferation of erythroid precursors [9]. However, other investigators have failed to confirm these results, suggesting other potential mechanisms [10, 11] since surgical or medical correction of hyperparathyroidism has been reported to be associated with an improvement in anemia in advanced CKD [12, 13].

PTH elevations in mild-to-moderate CKD are not as profound as more advanced CKD, and the association with anemia may be different in such a population. Indeed, in vitro, PTH appears to enhance heme synthesis at lower levels, while inhibiting synthesis at higher levels [14]. Furthermore, activation of the PTH receptor in osteoblasts results in the mobilization of hematopoietic stem cells, the precursors of all blood cells [15]. Among patients with primary hyperparathyroidism, circulating levels of these stem cells are elevated with levels directly correlated with PTH. Surgical correction of hyperparathyroidism restored the hematopoietic stem cell levels to those of controls [16]. These findings suggest that PTH may potentially enhance erythropoiesis at lower levels, while it may inhibit the process at higher levels.

We therefore sought to examine the association of PTH with hemoglobin levels in the Kidney Early Evaluation Program (KEEP) participants. KEEP is a free community-based CKD screening program targeting those who are at high risk for CKD [17]. The program is an ideal cohort to examine in this study due to availability of measures, namely hemoglobin and PTH, as well as other potential confounders. 


\section{CardioRenal Medicine}

\begin{tabular}{l|l}
\hline Cardiorenal Med 2013;3:120-127 \\
\hline DOI: $\underline{10.1159 / 000351229}$ & $\begin{array}{l}\text { @ 2013 S. Karger AG, Basel } \\
\text { www.karger.com/crm }\end{array}$ \\
\hline
\end{tabular}

Memon et al.: The Association between Parathyroid Hormone Levels and Hemoglobin in Diabetic and Nondiabetic Participants in the National Kidney Foundation's KEEP

\section{Methods}

Study Participants

KEEP methods have been described previously [17]. Participants were eligible to participate if they were $\geq 18$ years old and had a personal history of diabetes or hypertension or a first-degree relative with CKD, diabetes, or hypertension. For the purpose of this analysis, patients on dialysis or with a history of kidney transplant or dialysis were excluded. The KEEP database from November 1, 2005 through December 11, 2010 was examined. Since PTH levels were only measured among those with an estimated glomerular filtration rate (eGFR) $<60 \mathrm{ml} / \mathrm{min} / 1.73 \mathrm{~m}^{2}[18,19]$, the analysis was limited to this eGFR range among those with PTH and hemoglobin values recorded. Therefore, a total of 10,750 participants were included in this analysis. Participants in KEEP signed consent that information collected at screening can be used for research purposes. Analyses involving KEEP data have been approved by the Human Subjects Committee at the Minneapolis Medical Research Foundation (\#03-2262).

\section{Patient Characteristics}

Age, sex, race, education level, health insurance coverage, tobacco use, and physician care were derived from patient reports. Blood pressure, height, and weight were measured by trained personnel. BMI was calculated as weight $(\mathrm{kg})$ divided by height $\left(\mathrm{m}^{2}\right)$. Diabetes was defined as self-reported history of hyperglycemia or diabetes mellitus, use of glucose-lowering medications, fasting blood glucose $\geq 126 \mathrm{mg} / \mathrm{dl}$, or nonfasting blood glucose $\geq 200 \mathrm{mg} / \mathrm{dl}$. Cardiovascular disease was defined as self-reported history of heart angina, heart attack, heart bypass surgery, heart angioplasty, stroke, heart failure, abnormal heart rhythm, or coronary heart disease. Hypertension was defined as self-reported history of hypertension, use of antihypertensive medications, or blood pressure $\geq 130 / 85 \mathrm{~mm} \mathrm{Hg}$.

\section{Laboratory Data}

Calcium, phosphorus, and intact PTH were measured as previously described [18, 19]. Specifically, PTH was analyzed using the Immulite 2000 analyzer (Siemens Medical Solutions Diagnostics, www.usa.siemens. com). This assay measures both whole PTH and PTH fragments [20]. eGFR was estimated using the CKD Epidemiology Collaboration equation [21]. Albuminuria was defined as a spot urine albumin-creatinine ratio $\geq 30 \mathrm{mg} / \mathrm{g}$ (and included those with a ratio $>300$ ). Hemoglobin levels were measured from samples sent to a central laboratory.

\section{Statistical Methods}

Baseline characteristics were compared across PTH quintiles by the $\chi^{2}$ test or ANOVA, as appropriate. Multivariable linear regression was used to examine the effects of PTH on hemoglobin. PTH was modeled as a categorical and continuous (per standard deviation increase in natural log transformed PTH) predictor. Models were adjusted for age, sex, race, smoking status, high school education (yes/no), health insurance (yes/no), diabetes (yes/no), cardiovascular disease (yes/no), hypertension (yes/no), cancer (yes/no), albuminuria (yes/no), BMI, baseline eGFR, calcium, and phosphorus. Prespecified, multiplicative interaction terms were constructed to evaluate for the effects of diabetes, gender, albuminuria (yes/no), and eGFR category ( $\leq 45 \mathrm{vs.}>45 \mathrm{ml} / \mathrm{min} / 1.73 \mathrm{~m}^{2}$ ) using PTH as a continuous predictor. Interactions found to be statistically significant were presented in stratified form, and a linear association by strata was confirmed using PTH as a categorical predictor. A two-tailed $p$ value $<0.01$ was considered statistically significant to adjust for multiple comparisons.

\section{Results}

A total of 10,750 participants were included in the analysis. Baseline characteristics are provided in table 1 . The majority of the participants were female $(69.2 \%)$ and white $(68.8 \%)$, and almost half (47.4\%) of the participants had diabetes. Participants in the highest PTH quintiles were more likely to be black and had less than a high school education. They also had a higher prevalence of hypertension, cardiovascular disease, and albuminuria and were more likely to have seen a nephrologist. Participants in the highest PTH quintiles generally had lower calcium, eGFR, and hemoglobin levels as well as a higher BMI. 
Table 1. Baseline data across PTH quintiles

\begin{tabular}{|c|c|c|c|c|c|c|}
\hline PTH quintiles (pg/ml) & $\begin{array}{l}\text { 1st quintile } \\
\leq 41 \\
(n=2,204)\end{array}$ & $\begin{array}{l}\text { 2nd quintile } \\
>41-59 \\
(n=2,164)\end{array}$ & $\begin{array}{l}\text { 3rd quintile } \\
>59-80 \\
(n=2,171)\end{array}$ & $\begin{array}{l}\text { 4th quintile } \\
>80-114 \\
(n=2,091)\end{array}$ & $\begin{array}{l}\text { 5th quintile } \\
>114 \\
(\mathrm{n}=2,140)\end{array}$ & $\begin{array}{l}\mathrm{p} \text { value } \\
\text { for } \\
\text { trend }\end{array}$ \\
\hline Mean age \pm SD & $69.8 \pm 10.4$ & $70.1 \pm 10.7$ & $71.3 \pm 10.5$ & $71.5 \pm 10.6$ & $71.1 \pm 11.9$ & $<0.0001$ \\
\hline Male, \% & 32.1 & 32.4 & 32.2 & 33.4 & 32.2 & 0.7035 \\
\hline Race, $\%$ & & & & & & $<0.0001$ \\
\hline White & 76.5 & 73.5 & 68.9 & 66.8 & 57.5 & \\
\hline Black & 14.1 & 17.1 & 20.7 & 24.8 & 33.2 & \\
\hline Other & 9.4 & 9.4 & 10.4 & 8.5 & 9.3 & \\
\hline Smoker, \% & & & & & & 0.9810 \\
\hline Never & 59.3 & 60.2 & 59.4 & 60.3 & 59.5 & \\
\hline Quit & 35.7 & 34.6 & 35.6 & 34.8 & 35.1 & \\
\hline Current & 5.0 & 5.2 & 5.0 & 4.9 & 5.4 & \\
\hline High school education, $\%$ & 86.2 & 85.3 & 82.5 & 82.5 & 78.7 & $<0.0001$ \\
\hline Health insurance, \% & 92.3 & 90.8 & 91.6 & 91.2 & 90.8 & 0.1743 \\
\hline Prior nephrology care, \% & 8.8 & 7.3 & 7.6 & 10.7 & 16.7 & $<0.0001$ \\
\hline \multicolumn{7}{|l|}{ Comorbidities } \\
\hline Diabetes, $\%$ & 52.1 & 43.6 & 45.4 & 45.7 & 49.8 & 0.3996 \\
\hline Cardiovascular disease, $\%$ & 40.0 & 39.2 & 43.2 & 44.6 & 50.7 & $<0.0001$ \\
\hline Cancer, \% & 19.9 & 21.1 & 21.2 & 21.6 & 21.3 & 0.2534 \\
\hline Hypertension, \% & 91.4 & 91.6 & 91.7 & 93.5 & 95.7 & $<0.0001$ \\
\hline Albuminuria, $\%$ & 16.1 & 17.0 & 22.2 & 26.1 & 38.2 & $<0.0001$ \\
\hline \multicolumn{7}{|c|}{ Physical measurements } \\
\hline Mean systolic $\mathrm{BP} \pm \mathrm{SD}, \mathrm{mm} \mathrm{Hg}$ & $135.8 \pm 19.4$ & $137.2 \pm 19.5$ & $137.4 \pm 20.7$ & $137.9 \pm 20.0$ & $139.1 \pm 21.7$ & $<0.0001$ \\
\hline Mean BMI \pm SD & $29.7 \pm 6.1$ & $29.6 \pm 5.9$ & $29.6 \pm 6.1$ & $30.3 \pm 6.5$ & $31.3 \pm 7.1$ & $<0.0001$ \\
\hline \multicolumn{7}{|l|}{ Laboratory measurements } \\
\hline eGFR, $\mathrm{ml} / \mathrm{min} / 1.73 \mathrm{~m}^{2}$ & $49.6 \pm 8.4$ & $49.6 \pm 8.3$ & $48.7 \pm 8.8$ & $47.3 \pm 9.4$ & $41.9 \pm 12.3$ & $<0.0001$ \\
\hline eGFR category > 45 & 75.2 & 74.2 & 71.4 & 64.2 & 46.4 & $<0.0001$ \\
\hline Hemoglobin, g/dl & $13.4 \pm 1.5$ & $13.4 \pm 1.4$ & $13.3 \pm 1.5$ & $13.2 \pm 1.5$ & $12.8 \pm 1.6$ & $<0.0001$ \\
\hline Calcium, mg/dl & $9.8 \pm 0.5$ & $9.7 \pm 0.4$ & $9.6 \pm 0.4$ & $9.6 \pm 0.5$ & $9.5 \pm 0.6$ & $<0.0001$ \\
\hline Phosphorus, mg/dl & $3.74 \pm 0.58$ & $3.70 \pm 0.56$ & $3.69 \pm 0.59$ & $3.65 \pm 0.58$ & $3.67 \pm 0.69$ & $<0.0001$ \\
\hline
\end{tabular}

Upon multivariable adjustment, the direction of association of PTH with hemoglobin changed. As compared to the first PTH quintile, hemoglobin levels were $0.09 \mathrm{~g} / \mathrm{dl}$ (95\% CI: $0.01-0.18), 0.15 \mathrm{~g} / \mathrm{dl}(95 \% \mathrm{CI}: 0.07-0.24), 0.18 \mathrm{~g} / \mathrm{dl}$ (95\% CI: $0.09-0.26)$, and $0.13 \mathrm{~g} / \mathrm{dl}$ (95\% CI: 0.07-0.25) higher for the second, third, fourth, and fifth quintiles, respectively (table 2). Similarly, each standard deviation increase in natural log transformed PTH was associated with a $0.06 \mathrm{~g} / \mathrm{dl}(95 \% \mathrm{CI}: 0.03-0.09, \mathrm{p}=0.0003)$ increase in hemoglobin.

When using PTH as a continuous predictor, a significant effect modification was seen for diabetes ( $\mathrm{p}$ for interaction $=0.0003$ ) and the eGFR category ( $\mathrm{p}$ for interaction $=0.001$ ), but not for gender ( $\mathrm{p}$ for interaction $=0.05$ ) or albuminuria ( $\mathrm{p}$ for interaction $=0.85$ ) when accounting for multiple comparisons. For each standard deviation increase in natural log transformed PTH, hemoglobin increased by $0.1 \mathrm{~g} / \mathrm{dl}(95 \% \mathrm{CI}: 0.01-0.14, \mathrm{p}<0.0001)$ among diabetics but not among nondiabetics [0.01 g/dl (95\% CI: -0.03 to $0.05, \mathrm{p}=0.83$ )]. A linear relationship of PTH and hemoglobin among diabetics was confirmed using PTH as a categorical variable (data not shown). Similarly, for each standard deviation increase in natural log transformed PTH, hemoglobin increased by $0.07 \mathrm{~g} / \mathrm{dl}(95 \% \mathrm{CI}: 0.03-0.1, \mathrm{p}=0.0003)$ among those with an eGFR $>45$ but not among those with an eGFR $\leq 45,[-0.2 \mathrm{~g} / \mathrm{dl}(95 \% \mathrm{CI}$ : -0.07 to 0.03$), p=0.36$ ]. However, when using PTH as a categorical predictor, no linear asso- 


\section{CardioRenal Medicine}

Memon et al:: The Association between Parathyroid Hormone Levels and Hemoglobin in Diabetic and Nondiabetic Participants in the National Kidney Foundation's KEEP

Table 2. Linear regression of PTH with hemoglobin levels

\begin{tabular}{|c|c|c|c|c|c|}
\hline & 1st quintile & 2nd quintile & 3rd quintile & 4 th quintile & 5 th quintile \\
\hline \multicolumn{6}{|l|}{$\begin{array}{l}\text { Beta coefficient } \\
(95 \% \text { CI })\end{array}$} \\
\hline Unadjusted & ref & $0.03-0.06,0.12)$ & $-0.05(-0.14,0.04)$ & $-0.17(-0.26,-0.08)$ & $-0.57-0.66,-0.48)$ \\
\hline Adjusted & ref & $0.09(0.01,0.18)$ & $0.15(0.07,0.24)$ & $0.18(0.09,0.260)$ & $0.13(0.07,0.25)$ \\
\hline
\end{tabular}

Adjusted for age, sex, race, smoking status, high school education (yes/no), health insurance (yes/no), cardiovascular disease (yes/ no), diabetes (yes/no), hypertension (yes/no), cancer (yes/no), albuminuria (yes/no), BMI, baseline eGFR, calcium, and phosphorus.

ciation of PTH with hemoglobin was seen, and the direction of the association was similar for both strata (data not shown). Therefore, the association of PTH and hemoglobin was not modified by eGFR status.

\section{Discussion}

This study examines the association of PTH with hemoglobin in a large community-based sample of predialysis CKD patients. On unadjusted analysis, we found an inverse relationship of PTH with hemoglobin. However, after multivariable adjustment, the direction of association changed in that higher PTH levels were associated with a modest increase in hemoglobin. Furthermore, the association was stronger and significant only among diabetics.

Prior studies in KEEP have demonstrated a greater prevalence of anemia among diabetics with CKD and at earlier stages [22]. Erythropoietin levels have shown to be lower in diabetics than among nondiabetics prior to the development of significant CKD, indicating an effect of diabetes on the production of this hormone $[23,24]$. However, others have demonstrated a greater prevalence of anemia among diabetics with CKD despite similar erythropoietin levels to nondiabetics [25]. Thus, other factors may additionally be contributing to the anemia of CKD in diabetes.

The osteoblast has recently been described to be an important promoter of hematopoiesis [26]. Diabetes impairs osteoblast function [27] and is associated with a greater prevalence of adynamic bone disease in CKD patients [28]. A depressed osteoblast number and function in diabetic CKD may thus impair hematopoiesis, and higher PTH levels may be protective against this [29]. Indeed, osteoblast-specific constitutive activation of the PTH receptor results in an expansion of hematopoietic stem cells in vivo [26], possibly via the insulin growth factor (IGF) pathway [30].

IGF-1 may affect erythropoiesis via different pathways. Similar to erythropoietin, IGF-1 inhibits apoptosis of erythroid progenitor cells [31]. IGF-1 may additionally enhance the proliferation of erythroid progenitor cells at later stages of maturation [31, 32]. IGF-1 levels are lower in diabetic than nondiabetic CKD, and lower levels have been shown to be associated with anemia in diabetic but not nondiabetic CKD [25]. Thus, higher PTH levels may result in higher IGF-1 levels in diabetics, leading to higher hemoglobin levels. Unfortunately, IGF-1 levels are not measured in KEEP and this hypothesis requires further study.

There are other potential explanations for our findings. When controlling for eGFR, calcium, and phosphorus, participants with higher PTH level measurements may be more likely to be vitamin D deficient. However, vitamin D deficiency is associated with anemia in CKD [33] and thus unlikely to explain this association. Conversely, these patients are more probable to receive vitamin D therapy, which leads to higher hemoglobin levels. Neither 
Memon et al.: The Association between Parathyroid Hormone Levels and Hemoglobin in Diabetic and Nondiabetic Participants in the National Kidney Foundation's KEEP

vitamin D therapy nor vitamin D levels were recorded in KEEP, thus further studies are required to address these issues.

KEEP also did not record other important predictors of anemia such as folate, vitamin B12, and iron levels. The latter may also be an important confounder in this study. It has been postulated that iron may be an important regulator of fibroblast growth factor-23 (FGF-23) [34, 35]. Since FGF-23 may regulate PTH secretion [36], adjusting for the effects of iron and/ or FGF-23 would enhance our study, particularly since the secretion of FGF-23 may be modified by diabetic status [37]. However, FGF-23 and iron parameters were not measured in KEEP, and this too requires additional study.

Many of the patients, particularly of those with diabetes, were presumably treated with angiotensin-converting enzyme inhibitors or angiotensin receptor blockers as most $(>90 \%)$ had hypertension. Angiotensin II is an important regulator of erythropoiesis by directly stimulating erythroid progenitors and enhancing erythropoietin secretion [38]. Consequently, use of angiotensin-converting enzyme inhibitors and angiotesin receptor blockers has been associated with a reduction in hematocrit in a variety of populations, including the CKD population [39]. Unfortunately, KEEP did not record class-specific medications, and the inability to adjust for the confounding effect of these agents is another limitation to our study.

Strengths of the current study include the use of a wide, community-based, national CKD sample with available measures of PTH and hemoglobin. However, there are several limitations beyond the non-measured parameters mentioned above. First, the cross-sectional nature of this study does not imply the direction of the association nor does it imply causation. Second, the lack of important confounders, both known and unknown ones, limit the conclusions of an independent effect of PTH. Third, single measurements of both the predictor and main outcome variable may have led to a misclassification bias in the results. Fourth, the relative change in hemoglobin per change in PTH was rather modest and may be within the normal variability of the assay. Fifth, overadjustment in the multivariable model may have occurred, biasing our results. Finally, although we described a biologic plausibility of the effect modification for diabetes, this is the first study to directly examine such modification, and thus the subgroup analysis should be interpreted with caution. Despite these limitations, we feel our findings are unique and both add to the literature examining the association of PTH and hemoglobin levels in CKD and provide a rationale for further prospective studies along these lines.

In conclusion, in a large community-based sample of CKD, higher PTH levels were associated with higher hemoglobin levels among diabetics but not among nondiabetics. The mechanisms behind this association require additional study.

\section{Acknowledgements}

The KEEP Investigators are Peter A. McCullough, Adam Whaley-Connell, Andrew S. Bomback, Kerri Cavanaugh, Linda Fried, Claudine Jurkovitz, Mikhail Kosiborod, Samy McFarlane, Rajnish Mehrotra, Keith C. Norris, Rulan Savita Parekh, Carmen Peralta, Georges Saab, Stephen Seliger, Michael Shlipak, Lesley Inker, Manjula Kurella Tamura, John Wang; ex officio: Bryan Becker, Allan Collins, Nilka Ríos Burrows, Lynda A. Szczech, Joseph Vasssalotti; advisory group: George Bakris, Wendy Brown; data coordinating center: ShuCheng Chen.

KEEP is a program of the National Kidney Foundation Inc. and is supported by Amgen, Abbott, Siemens, Astellas, Fresenius Medical Care, Genzyme, LifeScan, Nephroceuticals, and Pfizer. Dr. Whaley-Connell receives support from the Veteran's Affairs Career Development Award-2, National Institutes of Health (NIH) grant R03AG040638-01, and American Society of Nephrology - Association of Specialty Professors - National Institute on Aging Development Grant in Geriatric Nephrology. Dr. Norris receives support from NIH grants MD007598 (formerly RR026138), MD000182, and UL1TR000124. 


\section{CardioRenal Medicine}

\begin{tabular}{l|l}
\hline Cardiorenal Med 2013;3:120-127 \\
\hline DOI: $\underline{10.1159 / 000351229}$ & $\begin{array}{l}\text { () } 2013 \text { S. Karger AG, Basel } \\
\text { www.karger.com/crm }\end{array}$ \\
\hline
\end{tabular}

Memon et al.: The Association between Parathyroid Hormone Levels and Hemoglobin in Diabetic and Nondiabetic Participants in the National Kidney Foundation's KEEP

\section{References}

1 Astor BC, Munter P, Levin A, Eustace JA, Coresh J: Association of kidney function with anemia: the Third National Health and Nutrition Examination Survey (1988-1994). Arch Intern Med 2002;162:1401-1408.

- 2 Hsu Cy, McCulloch CE, Curhan GC: Epidemiology of anemia associated with chronic renal insufficiency among adults in the United States: results from the Third National Health and Nutrition Examination Survey. J Am Soc Nephrol 2002;13:504-510.

3 Wagner M, Alam A, Zimmermann J, Rauh K, Koljaja-Batzner A, Raff U, Wanner C, Schramm L: Endogenous erythropoietin and the association with inflammation and mortality in diabetic chronic kidney disease. Clin J Am Soc Nephrol 2011;6:1573-1579.

$\checkmark 4$ Pfeffer MA, Burdmann EA, Chen CY, Cooper ME, de Zeeuw D, Eckardt KU, Feyzi JM, Ivanovich P, Kewalramani R, Levey AS, Lewis EF, McGill JB, McMurray JJV, Parfrey P, Parving HH, Remuzzi G, Singh AK, Solomon SD, Toto R: A trial of darbepoetin alfa in type 2 diabetes and chronic kidney disease. N Engl J Med 2009;361:2019-2032.

- 5 Singh AK, Szczech L, Tang KL, Barnhart H, Sapp S, Wolfson M, Reddan D: Correction of anemia with epoetin alfa in chronic kidney disease. N Engl J Med 2006;355:2085-2098.

- 6 Finkelstein FO, Story K, Firanek C, Mendelssohn D, Barre P, Takano T, Soroka S, Mujais S: Health-related quality of life and hemoglobin levels in chronic kidney disease patients. Clin J Am Soc Nephrol 2009;4:33-38.

- 7 Rao DS, Shih MS, Mohini R: Effect of serum parathyroid hormone and bone marrow fibrosis on the response to erythropoietin in uremia. N Engl J Med 1993;328:171-175.

8 Bogin E, Massry SG, Levi J, Djaldeti M, Bristol G, Smith J: Effect of parathyroid hormone on osmotic fragility of human erythrocytes. J Clin Invest 1982;69:1017-1025.

- 9 Meytes D, Bogin E, Ma A, Dukes PP, Massry SG: Effect of parathyroid hormone on erythropoiesis. J Clin Invest 1981;67:1263-1269.

$\checkmark 10$ Delwiche F, Garrity MJ, Powell JS, Robertson RP, Adamson JW: High levels of the circulating form of parathyroid hormone do not inhibit in vitro erythropoiesis. J Lab Clin Med 1983;102:613-620.

11 Foulks CJ, Mills GM, Wright LF: Parathyroid hormone and anaemia - an erythrocyte osmotic fragility study in primary and secondary hyperparathyroidism. Postgrad Med J 1989;65:136-139.

-12 Trunzo JA, McHenry CR, Schulak JA, Wilhelm SM: Effect of parathyroidectomy on anemia and erythropoietin dosing in end-stage renal disease patients with hyperparathyroidism. Surgery 2008;144:915-919.

13 Fusaro M, D'Angelo A, Naso A, Frigo AC, Miozzo D, Gallieni M, Calò LA: Treatment with calcimimetic (cinacalcet) alters epoetin dosage requirements in dialysis patients: preliminary report. Ren Fail 2011;33:732735.

14 Levi J, Bessler H, Hirsch I, Djaldetti M: Increased RNA and heme synthesis in mouse erythroid precursors by parathyroid hormone. Acta Haematol 1979;61:125-129.

-15 Calvi LM, Adams GB, Weibrecht KW, Weber JM, Olson DP, Knight MC, Martin RP, Schipani E, Divieti P, Bringhurst FR, Milner LA, Kronenberg HM, Scadden DT: Osteoblastic cells regulate the haematopoietic stem cell niche. Nature 2003;425:841-846.

16 Brunner S, Theiss HD, Murr A, Negele T, Franz WM: Primary hyperparathyroidism is associated with increased circulating bone marrow-derived progenitor cells. Am J Physiol Endocrinol Metab 2007;293:E1670-E1675.

17 Brown WW, Peters RM, Ohmit SE, Keane WF, Collins A, Chen SC, King K, Klag MJ, Molony DA, Flack JM: Early detection of kidney disease in community settings: the Kidney Early Evaluation Program (KEEP). Am J Kidney Dis 2003;42:22-35.

18 Saab G, Chen SC, Li S, Bomback AS, Whaley-Connell AT, Jurkovitz CT, Norris KC, McCullough PA: Association of physician care with mortality in Kidney Early Evaluation Program (KEEP) participants. Am J Kidney Dis 2012;59:S34-S39.

19 Saab G, Whaley-Connell A, Bombeck A, Kurella TM, Li S, Chen SC, McFarlane SI, Sowers JR, Norris K, Bakris GL, McCullough PA: The Association between parathyroid hormone levels and the cardiorenal metabolic syndrome in non-diabetic chronic kidney disease. Cardiorenal Med 2011;1:123-130.

20 Martin KJ, Olgaard K, Coburn JW, Coen GM, Fukagawa M, Langman C, Malluche HH, McCarthy JT, Massry SG, Mehls O, Salusky IB, Silver JM, Smogorzewski MT, Slatopolsky EM, McCann L: Diagnosis, assessment, and treatment of bone turnover abnormalities in renal osteodystrophy. Am J Kidney Dis 2004;43:558-565.

21 Levey AS, Stevens LA, Schmid CH, Zhang YL, Castro AF III, Feldman HI, Kusek JW, Eggers P, Van LF, Greene T, Coresh J: A new equation to estimate glomerular filtration rate. Ann Intern Med 2009;150:604-612.

22 El-Achkar TM, Ohmit SE, McCullough PA, Crook ED, Brown WW, Grimm R, Bakris GL, Keane WF, Flack JM: Higher prevalence of anemia with diabetes mellitus in moderate kidney insufficiency: the Kidney Early Evaluation Program. Kidney Int 2005;67:1483-1488.

23 Bosman DR, Winkler AS, Marsden JT, Macdougall IC, Watkins PJ: Anemia with erythropoietin deficiency occurs early in diabetic nephropathy. Diabetes Care 2001;24:495-499.

-24 Winkler AS, Marsden J, Chaudhuri KR, Hambley H, Watkins PJ: Erythropoietin depletion and anaemia in diabetes mellitus. Diabet Med 1999;16:813-819.

25 Kim DH, Kim TY, Kim SM, Yoo SJ, Oh DJ, Yu SH: IGF-1 is an independent risk factor for anemia in diabetic predialysis patients. Korean J Intern Med 2007;22:186-191.

26 Calvi LM, Adams GB, Weibrecht KW, Weber JM, Olson DP, Knight MC, Martin RP, Schipani E, Divieti P, Bringhurst FR, Milner LA, Kronenberg HM, Scadden DT: Osteoblastic cells regulate the haematopoietic stem cell niche. Nature 2003;425:841-846. 


\section{CardioRenal Medicine}

\begin{tabular}{l|l}
\hline Cardiorenal 2013;3:120-127 \\
\hline DOI: $10.1159 / 000351229$ & $\begin{array}{l}\text { @ } 2013 \text { S. Karger AG, Basel } \\
\text { www.karger.com/crm }\end{array}$ \\
\hline
\end{tabular}

Memon et al.: The Association between Parathyroid Hormone Levels and Hemoglobin in Diabetic and Nondiabetic Participants in the National Kidney Foundation's KEEP

27 Krakauer JC, McKenna MJ, Buderer NF, Rao DS, Whitehouse FW, Parfitt AM: Bone loss and bone turnover in diabetes. Diabetes 1995;44:775-782.

28 Malluche HH, Mawad H, Monier-Faugere MC: The importance of bone health in end-stage renal disease: out of the frying pan, into the fire? Nephrol Dial Transplant 2004;19:i9-i13.

29 Hruska KA, Saab G, Mathew S, Lund R: Renal osteodystrophy, phosphate homeostasis, and vascular calcification. Semin Dial 2007;20:309-315.

30 Lee JH, Hwang KJ, Kim MY, Lim YJ, Seol IJ, Jin HJ, Jang YK, Choi SJ, Oh W, Cho YH, Lee YH: Human parathyroid hormone increases the mRNA expression of the IGF system and hematopoietic growth factors in osteoblasts, but does not influence expression in mesenchymal stem cells. J Pediatr Hematol Oncol 2012;34:491-496.

-31 Muta K, Krantz SB, Bondurant MC, Wickrema A: Distinct roles of erythropoietin, insulin-like growth factor I, and stem cell factor in the development of erythroid progenitor cells. J Clin Invest 1994;94:34-43.

32 Ratajczak J, Zhang Q, Pertusini E, Wojczyk BS, Wasik MA, Ratajczak MZ: The role of insulin (INS) and insulinlike growth factor-I (IGF-I) in regulating human erythropoiesis. Studies in vitro under serum-free conditions - comparison to other cytokines and growth factors. Leukemia 1998;12:371-381.

33 Saab G, Young DO, Gincherman Y, Giles K, Norwood K, Coyne DW: Prevalence of vitamin D deficiency and the safety and effectiveness of monthly ergocalciferol in hemodialysis patients. Nephron Clin Pract 2007; 105:c132-c138.

-34 Braithwaite V, Jarjou LMA, Goldberg GR, Prentice A: Iron status and fibroblast growth factor-23 in Gambian children. Bone 2012;50:1351-1356.

35 Durham BH, Joseph F, Bailey LM, Fraser WD: The association of circulating ferritin with serum concentrations of fibroblast growth factor-23 measured by three commercial assays. Ann Clin Biochem 2007;44:463-466.

-36 Ben-Dov IZ, Galitzer H, Lavi-Moshayoff V, Goetz R, Kuro-o M, Mohammadi M, Sirkis R, Naveh-Many T, Silver J: The parathyroid is a target organ for FGF23 in rats. J Clin Invest 2007;117:4003-4008.

-37 Yoda K, Imanishi Y, Yoda M, Mishima T, Ichii M, Yamada S, Mori K, Emoto M, Inaba M: Impaired response of FGF-23 to oral phosphate in patients with type 2 diabetes: A possible mechanism of atherosclerosis. J Clin Endocrinol Metab 2012;97:E2036-E2043.

-38 Vlahakos DV, Marathias KP, Madias NE: The role of the renin-angiotensin system in the regulation of erythropoiesis. Am J Kidney Dis 2010;56:558-565.

-39 Marathias KP, Agroyannis B, Mavromoustakos T, Matsoukas J, Vlahakos DV: Hematocrit-lowering effect following inactivation of renin-angiotensin system with angiotensin converting enzyme inhibitors and angiotensin receptor blockers. Curr Top Med Chem 2004;4:483-486. 